\title{
Synthesis, Characterization and Thermal Properties of Palladium(II) Complexes Containing Phenyltetrazole. Crystal Structure of trans- $\left[\mathrm{C}_{40} \mathrm{H}_{64} \mathbf{N}_{8} \mathrm{O}_{2} \mathbf{P d C l}_{2}\right]$
}

\author{
Hugo Gallardo $^{a}$, Iêda Maria Begnini ${ }^{b}$, Ademir Neves $^{a}$ and Ivo Vencato ${ }^{a}$ \\ ${ }^{a}$ Departamento de Química, Universidade Federal de Santa Catarina, 88040-900, Florianópolis - SC, Brazil \\ ${ }^{b}$ Departamento de Química, Universidade Regional de Blumenau, 89010-971, Blumenau - SC, Brazil
}

\begin{abstract}
Neste trabalho, descreve-se a síntese de novos ligantes e dos seus complexos de Pd(II) com os ligantes 5-(n-alcoxifenil)-2-n-alquiltetrazol (L) e e $\alpha, \omega$-bis-[5-(4-pentoxifenil)-2-alcanotetrazois] (L $\left.\mathbf{L}^{2}\right)$. A determinação estrutural através de difração de raios- $X$ do complexo de paládio contendo $\mathbf{L}^{\mathbf{1}}$ revela uma estrutura mononuclear na qual a geometria do cromóforo $\mathrm{Pd}\left(\mathrm{L}^{1}\right)_{2} \mathrm{Cl}_{2}$ é plana e possui um centro de inversão sobre o átomo de paládio.As moléculas de feniltetrazol estão ligadas ao íon metálico de forma monodentada e trans entre si, através de uma ligação $\sigma$, Pd-N1. Para o complexo de paládio contendo $\mathbf{L}^{\mathbf{2}}$, propõe-se uma estrutura dinuclear, $\left(\left[\mathrm{Pd}_{2}\left(\mathrm{~L}^{2}\right)_{2} \mathrm{Cl}_{4}\right]\right)$, com base em dados de espectroscopia de RMN e IV.
\end{abstract}

The new 5-(n-alkoxyphenyl)-2-n-alkyltetrazole (L1) and $\alpha, \omega$-bis-[5-(4-pentoxyphenyl)-2alkanetetrazoles] ( $\left.\mathbf{L}^{2}\right)$ ligands and their Pd(II) complexes have been synthesized. The X-ray diffraction study of the palladium complex with $\mathbf{L} \mathbf{1}$ reveals a mononuclear structure in which the geometry of the $\mathrm{Pd}\left(\mathrm{L}^{1}\right)_{2} \mathrm{Cl}_{2}$ chromophore is planar as required by the inversion center at the palladium atom, where each molecule of phenyltetrazole binds to the metal ion in a monodentate fashion via a Pd-N1 $\sigma$-bond. For the palladium complex with $\mathbf{L}^{2}$, a dinuclear structure $\left(\left[\mathrm{Pd}_{2}\left(\mathrm{~L}^{2}\right)_{2} \mathrm{Cl}_{4}\right]\right)$ has been proposed on the basis of NMR and IR spectroscopy.

Keywords: palladium, phenyltetrazole, crystal structure analysis

\section{Introduction}

Liquid crystals have been known for more than 100 years, but the number of structural types and classes of chemical compounds capable of exhibiting mesomorphic properties has increased significantly only during the last 15-20 years, for example, metal-containing liquid crystals, which are termed "metallomesogens", that combine the variety and range of metal based coordination chemistry with the extraordinary physical properties exhibited by liquid crystals 1,2 .

Organic liquid crystals can be divided into thermotropic and lyotropic. Thermotropic can be further subdivided into calamitic and discotic, which are obtained with rod-like and disc-like molecules, respectively. The remarkable variety of geometries available in addition to the linear, trigonal and tetrahedral coordination geometries exhibited by carbon, and the incorporation of a metal immediately opens up a wide choice of new geo-

*e-mail: hugo@qmc.ufsc.br metric shapes. The coordination geometries of the central metals are also important; thus, linear, square planar, square pyramidal, or trigonal bipyramidal lend themselves to forming calamitic or discotic mesomorphic phases. Further important effects arise from the large and polarizable electron density which is a feature of metal atoms and, since many metal ions of the d- and fblock elements have unpaired electrons and are colored, their inclusion opens up the possibilities of the incorporation of new and exciting physical properties into liquid crystals 3,4 .

Compounds containing the $\mathrm{N}\left(\mathrm{sp}^{2}\right)-\mathrm{Pd}-\mathrm{C}\left(\mathrm{sp}^{2}\right)$ five member metallacycle, wherein both the carbon and nitrogen atoms are part of the aromatic ring are usually obtained from the reaction between palladium(II) salts and heteroaromatic species such as 2-phenylpyridine or structurally related compounds ${ }^{5}$. Recently, it was reported that palladium(II) complexes with organic liquid crystal materials containing the azobenzene or Shiff base frames, bonded through a metal-carbon s bond and having a metal-metal chloride bridge display mesophases ${ }^{6}$. 
This work reports the synthesis and characterization of a new $\operatorname{Pd}(\mathrm{II})$ complex with 5-(n-alkoxyphenyl)-2-nalkyltetrazole. We have explored the reaction between palladium(II) chloride and phenyltetrazole, in order to obtain an ortho-cyclometallated complex to investigate the influence of the tetrazol ring on the mesomorphic properties of this compound.

\section{Experimental}

All reagents were purchased from Aldrich Chemical Company (USA) and solvents were used as received from Merck.

\section{Physical measurements}

Elemental analyses were performed on a Perkin-Elmer model 2400 instrument. Infrared spectra were recorded on a Perkin-Elmer model 781 spectrometer in $\mathrm{KBr}$ disk or film. ${ }^{1} \mathrm{H}$ and ${ }^{13} \mathrm{C}$ NMR spectra were recorded on a BrukerAC-200F spectrometer at $200 \mathrm{MHz}$ and $50.4 \mathrm{MHz}$ respectively. Chemical shifts are reported relative to tetramethylsilane and in units of ppm. The coupling constants of ${ }^{13} \mathrm{C}-\mathrm{H}$ were measured directly from the measured coupled spectra, in all the cases where there was no superposition of the multiplets. Visible spectra were recorded in $\mathrm{CHCl}_{3}$ with a Perkin-Elmer Lambda 19 spectrometer. The transition temperatures for compounds were observed by optical microscopy using a Leitz Ortholux polarizing microscope in conjunction with a Mettler FP 52 heating stage.

\section{Preparation of 5-(4-Alkoxyphenyl)tetrazole (2)}

A solution of 4-pentoxybenzonitrile $(28.4 \mathrm{~g}, 0.15$ mol), sodium azide (39.0 g, $0.60 \mathrm{~mol})$, ammonium chloride $(32.1 \mathrm{~g}, 0.60 \mathrm{~mol})$ and dry dimethylformamide (DMF) $\left(100 \mathrm{~cm}^{3}\right)$ was stirred overnight at $100^{\circ} \mathrm{C}$ under nitrogen. After cooling, the reaction mixture was poured into 500 $\mathrm{cm}^{3}$ of water and acidified with $2 \mathrm{~mol} \mathrm{dm}{ }^{-3} \mathrm{HCl}$ solution (attention: hydrazoic acid is formed!). The white precipitate was isolated by filtration, washed with water and recrystallized from ethanol/water. Data for 5-(pentoxyphenyl)tetrazole $(27.4 \mathrm{~g}, 80 \%)$; white solid, m.p. 178.0$180.0{ }^{\circ} \mathrm{C}$ (ethanol/water); IR $v_{\max } / \mathrm{cm}^{-1} 2942,2870$, 1614, 1502, 1296, 1262, 840, $720(\mathrm{KBr}) ;{ }^{1} \mathrm{H}$ NMR $\left(\mathrm{CDCl}_{3}, 200 \mathrm{MHz}\right) \delta 8.00(\mathrm{~d}, J 8.4 \mathrm{~Hz}, 2 \mathrm{H}), 7.61(\mathrm{~d}, J 8.4$ $\mathrm{Hz}, 2 \mathrm{H}$ ), 3.95 (t, J6.6 Hz, 2H, - $\mathrm{OCH}_{2^{-}}$), 1.76 (quint., $2 \mathrm{H}$, $\mathrm{OCH}_{2} \mathrm{CH}_{2^{-}}$), 1.40-1.20 (m, 4H, -2 $\left.\mathrm{CH}_{2^{-}}\right), 0.92$ (t, $3 \mathrm{H}$, $\left.\mathrm{CH}_{3}\right) ;{ }^{13} \mathrm{C} \mathrm{NMR}\left(\mathrm{CDCl}_{3}, 50.4 \mathrm{MHz}\right) \delta 166.36\left(\mathrm{CN}_{4}\right)$, $161.56,129.01,120.73,115.48,53.81\left(-\mathrm{OCH}_{2^{-}}\right), 29.55$, $26.95,23.11,14.68$.

\section{Preparation of 5-(4-alkoxyphenyl)-2-alkyltetrazoles (L1a,b)}

A solution of 5-(4-pentoxyphenyl)tetrazole (1.85 g, $8.0 \mathrm{mmol})$, octylbromide $(1.54 \mathrm{~g}, 8.0 \mathrm{mmol}), \mathrm{K}_{2} \mathrm{CO}_{3}(1.1$ $\mathrm{g}, 8.0 \mathrm{mmol})$ and cyclohexanone $\left(100 \mathrm{~cm}^{3}\right)$ was refluxed for $56 \mathrm{~h}$, cooled to room temperature and the solid formed was filtered. The solvent was concentrated in a rotary evaporator and the residue was recrystallized from ethanol/water to give the pure product. Data for 5-(pentoxyphenyl)-2-octyltetrazole, (L1 $\mathbf{a}),(1.6 \mathrm{~g}, 59 \%)$; white solid, m.p. 36.5-38.1 ${ }^{\circ} \mathrm{C}$ (ethanol/water); IR $v_{\max } / \mathrm{cm}^{-1} 2918$, 2852, 1616, 1462, 1254, 840, $729(\mathrm{KBr}) ;{ }^{1} \mathrm{H} \mathrm{NMR}\left(\mathrm{CDCl}_{3}\right.$, $200 \mathrm{MHz}) \delta 8.00(\mathrm{~d}, J 8.4 \mathrm{~Hz}, 2 \mathrm{H}), 6.93(\mathrm{~d}, J 8.4 \mathrm{~Hz}, 2 \mathrm{H})$, $4.56\left(\mathrm{t}, J 7.0 \mathrm{~Hz}, 2 \mathrm{H},-\mathrm{NCH}_{2}-\right), 3.95\left(\mathrm{t}, J 6.6 \mathrm{~Hz}, 2 \mathrm{H},-\mathrm{OCH}_{2}-\right.$ ), 1.98 (quint., $2 \mathrm{H},-\mathrm{NCH}_{2} \mathrm{CH}_{2}$ ), 1.76 (quint., $2 \mathrm{H}$, $\mathrm{OCH}_{2} \mathrm{CH}_{2}$ ) $, 1.40-1.20\left(\mathrm{~m}, 14 \mathrm{H},-7 \mathrm{CH}_{2}-\right), 0.92-0.78$ (m, $\left.6 \mathrm{H},-2 \mathrm{CH}_{3}\right) ;{ }^{13} \mathrm{C} \mathrm{NMR}\left(\mathrm{CDCl}_{3}, 50.4 \mathrm{MHz}\right) \delta 165.38(\mathrm{~s}$, $\mathrm{CN}_{4}$ ), $161.48(\mathrm{~s}), 128.02(\mathrm{~d}, J 166.05 \mathrm{~Hz}), 120.63(\mathrm{~s}), 115.41$ (d, $J 165.70 \mathrm{~Hz}), 68.67\left(\mathrm{t}, J 142.62 \mathrm{~Hz},-\mathrm{NCH}_{2}-\right), 53.73$ (t, $\left.J 142.06 \mathrm{~Hz},-\mathrm{OCH}_{2^{-}}\right), 30.33,29.89,29.71,29.45,29.34$, 28.82, 26.88, 23.09, 14.74 (q, J 121.93 Hz). Data for 5(tetradecyloxyphenyl)-2-tetradecyltetrazole, $\left(\mathbf{L}^{\mathbf{1}} \mathbf{b}\right),(2.5 \mathrm{~g}$, 56\%); white solid, m.p. 74.3-75.9 ${ }^{\circ} \mathrm{C}$ (ethanol/water); IR $v_{\text {max }} / \mathrm{cm}^{-1} 2918,2852,1618,1464,1254,840,729(\mathrm{KBr})$; ${ }^{1} \mathrm{H} \mathrm{NMR}\left(\mathrm{CDCl}_{3}, 200 \mathrm{MHz}\right) \delta 8.01(\mathrm{~d}, J 8.4 \mathrm{~Hz}, 2 \mathrm{H}), 6.91$ (d, J 8.4 Hz, 2H), 4.55 (t, J7.0 Hz, 2H, $-\mathrm{NCH}_{2}$ ), 3.93 (t, J6.6 $\mathrm{Hz}, 2 \mathrm{H},-\mathrm{OCH}_{2}$ ), 1.97 (quint., $2 \mathrm{H},-\mathrm{NCH}_{2} \mathrm{CH}_{2}$ ), 1.76 (quint., $\left.2 \mathrm{H},-\mathrm{OCH}_{2} \mathrm{CH}_{2}-\right), 1.40-1.20\left(\mathrm{~m}, 44 \mathrm{H},-22 \mathrm{CH}_{2}-\right), 0.92-0.78$ $\left(\mathrm{m}, 6 \mathrm{H},-2 \mathrm{CH}_{3}\right) ;{ }^{13} \mathrm{C} \mathrm{NMR}\left(\mathrm{CDCl}_{3}, 50.4 \mathrm{MHz}\right) \delta 165.18$ $\left(\mathrm{CN}_{4}\right), 161.47,128.22,120.66,115.44,68.77,53.81,30.37$, 29.99, 29.81, 29.55, 29,44, 29.34, 28.82, 26.88, 26,34, $23.11,14.73$.

\section{Preparation of $\alpha, \omega$ Bis-[5-(4-pentoxyphenyl)-2-alkanetetrazoles] (L2a,b,c)}

5-(4-pentoxyphenyl)tetrazole, $(1.00 \mathrm{~g}, 4.30 \mathrm{mmol})$ was dissolved in $15 \mathrm{~cm}^{3}$ of cyclohexanone with stirring and to the solution was added $\alpha, \omega$-dibromoetane $(0.4 \mathrm{~g}, 2.15$ $\mathrm{mmol})$ and $\mathrm{K}_{2} \mathrm{CO}_{3}(0.59 \mathrm{~g}, 4.30 \mathrm{mmol})$. The reaction mixture was heated under reflux for $56 \mathrm{~h}$, cooled to room temperature and filtered. The solvent was evaporated under reduced pressure and the residue was recrystallized from ethanol to give the pure product. Data for 1,2-Bis-[5-(4pentoxyphenyl)-2-ethanetetrazole, ( $\left.\mathbf{L}^{\mathbf{2}} \mathbf{a}\right),(0.83 \mathrm{~g}, 40 \%)$, white solid, m.p. 166.0-168.0 ${ }^{\circ} \mathrm{C}$ (ethanol); (Found: C, 63.57; H, 7.06; N, 22.65. Calc. for $\mathrm{C}_{26} \mathrm{H}_{34} \mathrm{~N}_{8} \mathrm{O}_{2}$ : C, 63.67; $\mathrm{H}, 6.93$; N , 22.85\%); IR $v_{\max } / \mathrm{cm}^{-1} 2920,2855,1616,1462$, $1254,840,720(\mathrm{KBr}) ;{ }^{1} \mathrm{H} \mathrm{NMR}\left(\mathrm{CDCl}_{3}, 200 \mathrm{MHz}\right) \delta 7.94$ (d, J $8.5 \mathrm{~Hz}, 4 \mathrm{H}), 6.90$ (d, J $8.5 \mathrm{~Hz}, 4 \mathrm{H}), 5.22$ (s, 4H, $2 \mathrm{NCH}_{2^{-}}$), 3.94 (t, J $6.5 \mathrm{~Hz}, 4 \mathrm{H},-2 \mathrm{OCH}_{2^{-}}$), 1.75 (quint., $4 \mathrm{H}$, $-\mathrm{OCH}_{2}-\mathrm{CH}_{2}$ ), 1.55-1.19 (m, 8H, -4CH $\left.2^{-}\right), 0.87$ (t, 6H, - 
$\left.2 \mathrm{CH}_{3}\right) ;{ }^{13} \mathrm{C} \mathrm{NMR}\left(\mathrm{CDCl}_{3}, 50.4 \mathrm{MHz}\right) \delta 166.32\left(\mathrm{~s}, \mathrm{CN}_{4}\right)$, 161.69 (s), 129,10 (d, J 166.02 Hz), 119.89 (s), 115.47 (d, J $165.84 \mathrm{~Hz}$ ), 68.78 (t, J $142.62 \mathrm{~Hz},-\mathrm{NCH}_{2}$ ), 51.71 (t, J $\left.140.13 \mathrm{~Hz},-\mathrm{OCH}_{2}-\right), 30.35,30.02,29.53,28.82,23.11$, 14.67 (q, J $121.95 \mathrm{~Hz}$ ); Data for 1,6-Bis-[5-(4-pentoxyphenyl)-2-hexanetetrazole, ( $\left.\mathbf{L}^{2} \mathbf{b}\right),(0.93 \mathrm{~g}, 40 \%)$, white solid, m.p. 123.1-125. ${ }^{\circ} \mathrm{C}$ (ethanol); (Found: C, 65.57; H, 7.81, N, 21.00. Calc. for $\mathrm{C}_{30} \mathrm{H}_{42} \mathrm{~N}_{8} \mathrm{O}_{2}$ : C, 65.93; H, 7.69; N, 20.51\%); IR $v_{\max } / \mathrm{cm}^{-1} 2920,2855,1616,1462,1254$, $840,720(\mathrm{KBr}) ;{ }^{1} \mathrm{H} \mathrm{NMR}\left(\mathrm{CDCl}_{3}, 200 \mathrm{MHz}\right) \delta 8.03(\mathrm{~d}, J$ $8.5 \mathrm{~Hz}, 4 \mathrm{H}), 6.97$ (d, J 8.5 Hz, 4H), 4.60 (t, 4H, J 6,9 Hz, $2 \mathrm{NCH}_{2^{-}}$), 3.99 (t, J6.5 Hz, 4H, $-2 \mathrm{OCH}_{2^{-}}$), 2.04 (quint. $4 \mathrm{H}$, $-2 \mathrm{NCH}_{2} \mathrm{CH}_{2}$ ), 1.80 (quint. $4 \mathrm{H},-2 \mathrm{OCH}_{2} \mathrm{CH}_{2}$ ), $1.48-1.20$ $\left(\mathrm{m}, 12 \mathrm{H},-6 \mathrm{CH}_{2^{-}}\right), 0.92\left(\mathrm{t}, 6 \mathrm{H},-2 \mathrm{CH}_{3}\right) ;{ }^{13} \mathrm{C} \mathrm{NMR}\left(\mathrm{CDCl}_{3}\right.$, $50.4 \mathrm{MHz}) \delta 165.72\left(\mathrm{~s}, \mathrm{CN}_{4}\right), 161.47(\mathrm{~s}), 128,91(\mathrm{~d}, J 165.97$ $\mathrm{Hz}), 120.44$ (s), 115.44 (d, J $165.88 \mathrm{~Hz}), 68.76$ (t, J 142.33 $\mathrm{Hz},-\mathrm{NCH}_{2}$ ), 53.43 (t, J141.01 Hz, - $\mathrm{OCH}_{2}-$ ), 30.35, 30.02, 29.8, 29.56, 29.32, 28.82, 26.99, 23.11, 14.67 (q, $J$ 121.56). Data for 1,10-Bis-[5-(4-pentoxyphenyl)-2-decanetetrazole, $\left(\mathbf{L}^{2} \mathbf{c}\right),(0.90 \mathrm{~g}, 35 \%)$, white solid, m.p. $112.0-114.1^{\circ} \mathrm{C}$ (ethanol), (Found: C, 68.09; H, 8.68, N, 18.12. Calc. for $\mathrm{C}_{34} \mathrm{H}_{50} \mathrm{~N}_{8} \mathrm{O}_{2}$ : C, 67.77; H, 8.30; N, 18.60\%); IR $v_{\max } / \mathrm{cm}^{-1}$ 2920, 2855, 1616, 1462, 1254, 840, 720 (KBr); ${ }^{1} \mathrm{H}$ NMR $\left(\mathrm{CDCl}_{3}, 200 \mathrm{MHz}\right) \mathrm{d} 8.04(\mathrm{~d}, J 8.5 \mathrm{~Hz}, 4 \mathrm{H}), 6.93(\mathrm{~d}, J 8.5$ $\mathrm{Hz}, 4 \mathrm{H}), 4.53\left(\mathrm{t}, 4 \mathrm{H}, J 6,9 \mathrm{~Hz},-2 \mathrm{NCH}_{2}-\right), 3.94(\mathrm{t}, J 6.5 \mathrm{~Hz}$, $4 \mathrm{H}, 2 \mathrm{OCH}_{2}$ ), 1.96 (quint. $4 \mathrm{H},-2 \mathrm{NCH}_{2} \mathrm{CH}_{2}$ ) $), 1.74$ (quint. $4 \mathrm{H},-2 \mathrm{OCH}_{2} \mathrm{CH}_{2^{-}}$), 1.47-1.18 (m. $20 \mathrm{H},-10 \mathrm{CH}_{2}^{-}$), 0.87 (t, $\left.6 \mathrm{H},-2 \mathrm{CH}_{3}\right) ;{ }^{13} \mathrm{C} \mathrm{NMR}\left(\mathrm{CDCl}_{3}, 50.4 \mathrm{MHz}\right) \delta 165.61(\mathrm{~s}$, $\mathrm{CN}_{4}$ ), 161.44 (s), 128.89 (d, J $\left.165.98 \mathrm{~Hz}\right), 120.53$ (s), 115.42 (d, $J 165.73 \mathrm{~Hz}), 68.76$ (t, J $142.45 \mathrm{~Hz},-\mathrm{NCH}_{2}$ ), 53.71 (t, J141.06 Hz, - $\mathrm{OCH}_{2}$ ) $, 30.35,29.98,29.79,29.55$, 29.44, 28.83, 26.95, 23.11, 14.68 (q, J $122.12 \mathrm{~Hz}$ ).

\section{Preparation of dichlon-bis-[5-(4-alkoxyphenyl)-2-alkyltetrazole] palladium(II) $(\mathbf{3 a}, \mathbf{b})$}

A mixture of 5-(pentoxyphenyl)-2-octyltetrazole, $\left(\mathbf{L}^{\mathbf{1}} \mathbf{a}\right)$, $(0.55 \mathrm{~g}, 1.6 \mathrm{mmol}), \mathrm{PdCl}_{2}(0.28 \mathrm{~g}, 1.6 \mathrm{mmol})$ and glacial acetic acid $\left(37 \mathrm{~cm}^{3}\right)$ was heated under reflux and nitrogen atmosphere for $24 \mathrm{~h}$. The mixture was cooled to room temperature and the precipitate formed was filtered off and recrystallized from isopropanol. Data for dichloro-bis-[5-(4pentoxyphenyl)-2-octyltetrazole] palladium(II) (3a), (0.35 g, 50\%), yellow solid, m.p. 100.8-103.0 ${ }^{\circ} \mathrm{C}$ (isopropanol), (Found: C, 56.00; H, 7.63; N, 12.98. Calc. for $\left.\mathrm{C}_{40} \mathrm{H}_{64} \mathrm{~N}_{8} \mathrm{O}_{2} \mathrm{PdCl}_{2}: \mathrm{C}, 55.46 ; \mathrm{H}, 7.39 ; \mathrm{N}, 12.94 \%\right)$. IR $v_{\max }{ }^{\prime}$ $\mathrm{cm}^{-1}$ 2918, 2852, 1620, 1460, 1254, 840, 725, 348 (Pd-Cl), $306(\mathrm{Pd}-\mathrm{N})(\mathrm{KBr}) ;{ }^{1} \mathrm{H} \mathrm{NMR}\left(\mathrm{CDCl}_{3}, 200 \mathrm{MHz}\right) \delta 8.83(\mathrm{~d}, J$ $8.4 \mathrm{~Hz}, 4 \mathrm{H}), 7.11$ (d, J $8.4 \mathrm{~Hz}, 4 \mathrm{H}), 4.67$ (t, J7.0 Hz, 4H, $2 \mathrm{NCH}_{2}$ ), 4.09 (t, J 6.5 Hz, 4H, $-2 \mathrm{OCH}_{2^{-}}$), 2.10 (quint., 4H, $2 \mathrm{NCH}_{2} \mathrm{CH}_{2}$ ), 1.87 (quint., $4 \mathrm{H},-2 \mathrm{OCH}_{2} \mathrm{CH}_{2}$ ) $), 1.60-1.30$ (m, $\left.28 \mathrm{H},-14 \mathrm{CH}_{2}-\right), 1.01-0.86\left(\mathrm{~m}, 12 \mathrm{H},-4 \mathrm{CH}_{3}\right) ;{ }^{13} \mathrm{C} \mathrm{NMR}$ $\left(\mathrm{CDCl}_{3}, 50.4 \mathrm{MHz}\right) \delta 165.62\left(\mathrm{~s}, \mathrm{CN}_{4}\right), 162.50(\mathrm{~s}), 131.33(\mathrm{~d}$, $J 166.48 \mathrm{~Hz}), 117.24$ (s), 115.63 (d, $J 165.43 \mathrm{~Hz}), 68.83$ (t, $J$ $142.34 \mathrm{~Hz},-\mathrm{NCH}_{2^{-}}$), 55.86 (t, $J 141.19 \mathrm{~Hz},-\mathrm{OCH}_{2^{-}}$), 32.33, 29.88, 29.63, 29.39, 29.05 28.88, 26.96, 26.33, 23.36, 14.81 (q, J $121.93 \mathrm{~Hz}$ ). Data for dichloro-bis-[5-(4tetradecyloxyphenyl)-2-tetradecyltetrazole] palladium(II) (3b), $\left(0.46\right.$ g, 45\%), yellow solid, m.p. $109.0-110.0^{\circ} \mathrm{C}$ (isopropanol), (Found: C, 65.48; H, 10.07; N, 8.97. Calc. for $\mathrm{C}_{70} \mathrm{H}_{124} \mathrm{~N}_{8} \mathrm{O}_{2} \mathrm{PdCl}_{2}$ : C, 65.35 H, 9.70; N, 8.71\%). IR v $v_{\max }$ ' $\mathrm{cm}^{-1}$ 2920, 2852, 1620, 1460, 1254, 840, 725, 348 (Pd-Cl), $306(\mathrm{Pd}-\mathrm{N})(\mathrm{KBr}) ;{ }^{1} \mathrm{H} \mathrm{NMR}\left(\mathrm{CDCl}_{3}, 200 \mathrm{MHz}\right) \delta 8.85(\mathrm{~d}, J$ $8.6 \mathrm{~Hz}, 4 \mathrm{H}), 7.10$ (d, J 8.6 Hz, 4H), 4.66 (t, J7.0 Hz, 4H, $\left.2 \mathrm{NCH}_{2}{ }^{-}\right), 4.08\left(\mathrm{t}, J 6.5 \mathrm{~Hz}, 4 \mathrm{H},-2 \mathrm{OCH}_{2}\right.$ ) $), 2.15$ (quint., 4H, $2 \mathrm{NCH}_{2} \mathrm{CH}_{2}$ ), 1.85 (quint., $4 \mathrm{H},-2 \mathrm{OCH}_{2} \mathrm{CH}_{2}$ ) $), 1.60-1.26$ (m, $\left.88 \mathrm{H},-14 \mathrm{CH}_{2}-\right), 0.90-0.84\left(\mathrm{~m}, 12 \mathrm{H},-4 \mathrm{CH}_{3}\right) ;{ }^{13} \mathrm{C} \mathrm{NMR}$ $\left(\mathrm{CDCl}_{3}, 50.4 \mathrm{MHz}\right) \delta 165.61\left(\mathrm{~s}, \mathrm{CN}_{4}\right), 162.48(\mathrm{~s}), 131.60(\mathrm{~d}$, $J 166.55 \mathrm{~Hz}), 117.24$ (s), 115.37 (d, J165.33 Hz), 68.85 (t, $J$ $142.66 \mathrm{~Hz},-\mathrm{NCH}_{2}$ ), 55.86 (t, $J 141.20 \mathrm{~Hz},-\mathrm{OCH}_{2}$ ), 32.58 , 29.98, 29.72, 29.58, 29.15, 29.02, 28.89, 28.76, 26.98, 26.54, 23.41, 23.03, 14.80 (q, $J 121.90 \mathrm{~Hz})$.

\section{Preparation of tetrachloro-bis-[1,10-bis-[5-(4-pentoxyphenyl)- 2-decanetetrazole]dipalladium (II) (4c)}

A mixture of 1,10-Bis-[5-(4-pentoxyphenyl)-2-decane tetrazole], $\left(\mathbf{L}^{2} \mathbf{c}\right),(0.29 \mathrm{~g}, 0.48 \mathrm{mmol})$ and $\mathrm{PdCl}_{2}(0.18 \mathrm{~g}$, $1.03 \mathrm{mmol})$ in glacial acetic acid $\left(12 \mathrm{~cm}^{3}\right)$ was heated under reflux and dry $\mathrm{N}_{2}$ for $48 \mathrm{~h}$. The reaction mixture was cooled to room temperature and the precipitate formed was filtered off and recrystallized from ethanol to give $4 \mathrm{c}$. Data for tetrachloro-bis-[1,10-bis-[5-(4-pentoxyphenyl)2-decanetetrazole Jdipalladium(II) (4c) $(0.30 \mathrm{~g}, 40 \%)$ yellow solid, m.p. 164.0-167 ${ }^{\circ} \mathrm{C}$ (ethanol), (Found: C, 52.26; $\mathrm{H}, 6.61 ; \mathrm{N}, 14.36$. Calc. for $\mathrm{C}_{68} \mathrm{H}_{100} \mathrm{~N}_{16} \mathrm{O}_{4} \mathrm{Pd}_{2} \mathrm{Cl}_{4}$ : C, 52.35; H, 6.41; N, 14.37\%). IR $v_{\max } / \mathrm{cm}^{-1} 2918,2852$, 1620, 1460, 1254, 840, 725, 350 ( $\mathrm{Pd}-\mathrm{Cl}), 310$ (Pd-N) (KBr); ${ }^{1} \mathrm{H}$ NMR $\left(\mathrm{CDCl}_{3}, 200 \mathrm{MHz}\right) \delta 8.83(\mathrm{~d}, J 8.4 \mathrm{~Hz}, 8 \mathrm{H}), 7.19$ (d, J 8.4 Hz, 8H), $4.68\left(\mathrm{t}, J 7.0 \mathrm{~Hz}, 8 \mathrm{H}, 4 \mathrm{NCH}_{2}-\right), 4.10(\mathrm{t}, J$ $6.4 \mathrm{~Hz}, 8 \mathrm{H},-4 \mathrm{OCH}_{2}$ ), 2.10 (quint., $8 \mathrm{H}$ ), 1.87 (quint., $8 \mathrm{H}$ ), 1.47-1.37 (m, 40H), $0.98(\mathrm{t}, 12 \mathrm{H}) ;{ }^{13} \mathrm{C} \mathrm{NMR}\left(\mathrm{CDCl}_{3}, 50.4\right.$ $\mathrm{MHz}) \delta 165.60\left(\mathrm{~s}, \mathrm{CN}_{4}\right), 162.49(\mathrm{~s}), 131.35(\mathrm{~d}, J 166.78$ $\mathrm{Hz}), 117.24$ (s), 115.63 (d, J $164.99 \mathrm{~Hz}), 68.86$ (t, J 143.45 $\mathrm{Hz},-\mathrm{NCH}_{2}-$ ) 55.86 (t, J142.75 Hz, $-\mathrm{OCH}_{2}$ ), 32.33, 30.96, $30.33,29.91,29.78,29.67,29.56,2933,28.43,28,01$, $27.87,27.77,26.37,26,12,23,25,14.61$ (q, $J 122.33 \mathrm{~Hz}$ ).

\section{Crystallography}

Crystal Data. $\mathrm{C}_{40} \mathrm{H}_{64} \mathrm{~N}_{8} \mathrm{O}_{2} \mathrm{PdCl}_{2}, 3 \mathbf{a}, \mathrm{M}=866.29$, triclinic, $\mathrm{a}=7.053(1), \mathrm{b}=12.244(2), \mathrm{c}=13.013(3) \AA$, 
$\alpha=86.15(3), \beta=84.61(3), \gamma=78.40(3)^{\circ}, U=1094.6(3)$ $\AA^{3}, \mathrm{~T}=293 \mathrm{~K}$, space group $\mathrm{P}-1$ [no. 2], $\mathrm{Z}=1, \mu(\mathrm{MoK} \alpha)=$ $0.588 \mathrm{~mm}^{-1}, \mathrm{D}_{\mathrm{c}}=1.314 \mathrm{Mg} \mathrm{m}^{-3}, 4190$ reflections measured, 3845 unique, $\left(\mathrm{R}_{\text {int }}=0.021\right)$ which were used in all calculations. The final $\mathrm{wR}\left(\mathrm{F}^{2}\right)$ was 0.080 (all data) for 241 refined parameters.

\section{Results and Discussion}

\section{Phenyltetrazole ligands}

The synthetic route used to prepare the tetrazole ligands is shown in Scheme 1. The first step involves the formation of aromatic tetrazoles by the reaction of the corresponding $p$ alkoxylbenzonitrile with sodium azide ${ }^{7}$. Alkylation reaction with the appropriate alkyl halide furnished the 5-(4alkoxyphenyl)-2-alkyltetrazole, (L1 $\mathbf{a}, \mathbf{b})$, or $\alpha, \omega$-bis-[5-(4-

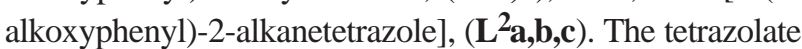
anion is an ambidentate system in which alkylation reactions can occur at the $\mathrm{N}-1$ or $\mathrm{N}-2$ positions, the relative proportions of which depend upon the conditions of the alkylation and the influence of the 5 -substituent ${ }^{8}$. However, in our case, spectroscopic evidence suggests that the $\mathrm{N}-2$ anion in the tetrazole ring is the nucleophile in alkylation reaction. The alkyl substituent at the 1- or 2-position can be readily distinguished by the ${ }^{1} \mathrm{H}$ and ${ }^{13} \mathrm{C}$ chemical shifts of the $\mathrm{N}$ alkyl group. Alkyl groups bonded to $\mathrm{N}-1$ are more shielded by $c a .0 .15-0.35 \mathrm{ppm}$ in the ${ }^{1} \mathrm{H}$ spectra and by $c a$. 2-6 ppm in the ${ }^{13} \mathrm{C}$ spectra to their corresponding $\mathrm{N}-2$ isomers ${ }^{9}$. The regioselectivity in the alkylation was confirmed by the analysis of the ${ }^{13} \mathrm{C}$ NMR chemical shifts of the carbon atom $\mathrm{C} 5$ in the tetrazole ring. For the ligands $\left(\mathbf{L}^{\mathbf{1}} \mathbf{a}, \mathbf{b}\right)$ and $\left(\mathbf{L}^{\mathbf{2}} \mathbf{a}, \mathbf{b}, \mathbf{c}\right)$ the chemical shift for C5 varied from 166.32 to $165.18 \mathrm{ppm}$, and following the work of Butler and Garvin ${ }^{10}$ in similar systems there is therefore a perfect distinction between the isomeric forms $\mathrm{N}-1$ and $\mathrm{N}-2$. This regioselectivity is due to the large steric hindrance at the $\mathrm{N}-1$ position considering the bulky and large alkylating agents used.

\section{Preparation of Pd(II) complexes with phenyltetrazole ligands ${ }^{11}$}

The Pd(II) complexes were prepared accordingly to the reaction scheme 2 . The reactions were done with $\mathrm{PdCl}_{2}$ and the respective phenyltetrazole ligand in glacial HOAc under $\mathrm{N}_{2}$ at $60^{\circ} \mathrm{C}$ for $24 \mathrm{~h}$. The reaction gives yellow solids, for complexes with $\mathbf{L}^{\mathbf{1}} \mathbf{a}, \mathbf{b}$ and $\mathbf{L}^{\mathbf{2}} \mathbf{c}$ ligands. With $\mathbf{L}^{\mathbf{2}} \mathbf{a}, \mathbf{b}$ ligands, no reaction took place under the same conditions, and all ligands were recovered, probably due to steric reasons. The analytical and NMR spectroscopic data for the products were consistent with the stoichiometry of mononuclear $\left[\mathrm{Pd}\left(\mathrm{L}^{1}\right)_{2} \mathrm{Cl}_{2}\right]$ or dinuclear complexes $\left[\mathrm{Pd}_{2}\left(\mathrm{~L}^{2}\right)_{2} \mathrm{Cl}_{4}\right]$ and monodentate coordination of the tetrazole ligand.

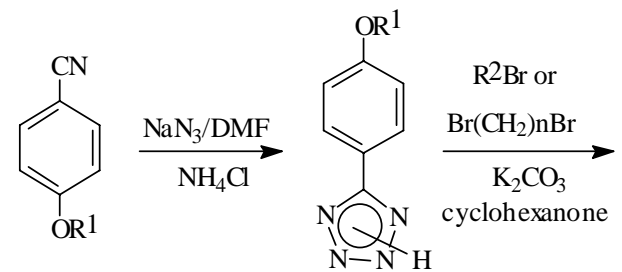

1<smiles>[R]Oc1ccc(-c2nnn([R])n2)cc1</smiles><smiles>CCn1nnc(-c2ccc(OC)cc2)n1</smiles>

L1

$\mathbf{L}^{2}$

$$
\begin{array}{ll}
\text { a } \mathrm{R}^{1}=\mathrm{C}_{5} \mathrm{H}_{11} \quad \mathrm{R}^{2}=\mathrm{C}_{8} \mathrm{H}_{17} & \text { a } \mathrm{R}^{1}=\mathrm{C}_{5} \mathrm{H}_{11}, \mathrm{n}=2 \\
\text { b } \mathrm{R}^{1}=\mathrm{C}_{14} \mathrm{H}_{29} \mathrm{R}^{2}=\mathrm{C}_{14} \mathrm{H}_{29} & \text { b } \mathrm{R}^{1}=\mathrm{C}_{5} \mathrm{H}_{11}, \mathrm{n}=6 \\
& \text { c } \mathrm{R}^{1}=\mathrm{C}_{5} \mathrm{H}_{11}, \mathrm{n}=10
\end{array}
$$

Scheme 1.<smiles></smiles>

Scheme 2. 
In principle, each of the three nitrogen atoms of the tetrazole ring is capable of acting as a coordination site. Structural studies have shown that tetrazole and its derivatives have a rich variety of coordination modes with transition metals ${ }^{12}$. In our case specifically, the phenyltetrazole ligand may act in one of three distinct coordination modes (Scheme 3): formation of (a) the organo-palladium compound, (b) bidentate coordination, (tetrazole may be bridging) and (c) monodentate nitrogen coordination. The difference in architecture, i.e., bond angles and bond distances in the tetrazole ring, depends mainly upon the difference in their coordination behavior. To date, no evidence has been found to support other coordination mode which does not involve bonding through the nitrogen lone pair.

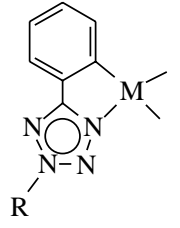

$\mathbf{a}$

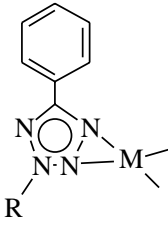

b

Scheme 3.

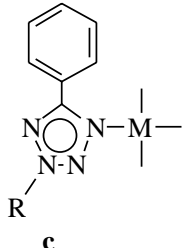

The IR spectra of the complexes show two stretching vibrations at 348 and $306 \mathrm{~cm}^{-1}(\mathbf{3 a}, \mathbf{b})$ and 350 and 310 $\mathrm{cm}^{-1}(\mathbf{4 c})$, assignable to $v_{\text {as }}(\mathrm{Pd}-\mathrm{Cl})$ and $v_{\text {as }}(\mathrm{Pd}-\mathrm{N})$, respectively, in the region expected for the cis/trans isomers ${ }^{13}$. The UV-Vis absorption spectrum of complex 3 a measured in chloroform solution shows an absorption band at 404 $\mathrm{nm}\left(\varepsilon=221.5 \mathrm{dm}^{3} \mathrm{~mol}^{-1} \mathrm{~cm}^{-1}\right)$, which was not observed in the spectrum of the free ligand. This absorption band is attributed to a d-d transition. The ligands and complexes were also characterized by ${ }^{1} \mathrm{H}$ and ${ }^{13} \mathrm{C}$ NMR spectroscopy. The complexes and the free ligands have similar spectra, but some small differences in the aromatic region indicate that complexation has been achieved. For example, the ${ }^{1} \mathrm{H}$ NMR spectra for the complexes $\mathbf{3 a}, \mathbf{b}$ or $\mathbf{4 c}$, in the AA'XX' system, $\Delta v / J>10$, the hydrogens on the ortho carbon atoms to the tetrazole ring, were shifted to higher frequency by $0.80 \mathrm{ppm}$, relative to their positions in the spectra of the free ligands. In the ${ }^{13} \mathrm{C}$ NMR spectra the major differences in the chemical shifts were detected in the ortho carbon to the tetrazole ring which is shifted to higher frequency $c a$. by $2.4 \mathrm{ppm}$ and in the aromatic carbon, $\mathrm{C} 1$, which is shifted to lower frequency by $3 \mathrm{ppm}$ relative to their positions in the spectra of the free ligands.

In all cases no cyclopalladation reaction was observed, since the monodentate coordination products were isolated. In fact, this behavior may be attributed to the non activation of the ortho position, due the presence of the tetrazole group, which is a strong electron-withdrawing substituent. It is well known that the cyclopalladation reaction proceeds by an electrophilic attack of the palladium ion on the aryl group, and this is not favored when electron-withdrawing groups are bonded, in ortho or para positions, to the palladation carbon ${ }^{14}$.

For complex 3a a yellow crystalline solid was obtained and the structure was confirmed by an X-ray diffraction study. Unfortunately, all attempts to grow single crystals suitable for X-ray analysis were unsuccessful for complexes $\mathbf{3 b}$ and $\mathbf{4 c}$. However, the analytical and NMR spectroscopic data are consistent with the stoichiometry of mononuclear complex for $\mathbf{3 b}$, with a similar coordination environment as in 3a (trans- $\left.\left[\mathrm{PdN}_{2} \mathrm{Cl}_{2}\right]\right)$. On the other hand, based on the structure of the ligand, the spectroscopic data (NMR and IR) and the mode of coordination of the tetrazole nitrogen in the mononuclear complex 3a, we tentatively propose a dinuclear structure for complex $\mathbf{4 c}$ as shown in Scheme 2. The complexes of phenyltetrazole do not exhibit mesomorphic properties.

\section{Crystal structure determination of compound $\mathbf{3 a}$}

Figure 1 shows the ZORTEP ${ }^{15}$ view of the molecular structure of 3a. The crystal structure consists of discrete monomeric molecules of $\left[\mathrm{Pd}(\mathrm{PhTz})_{2} \mathrm{Cl}_{2}\right]$ in which the $\mathrm{Pd}(\mathrm{II})$ ion involves an essentially square planar environment. Two phenyltetrazol and two chloride donors are coordinated in trans positions with respect to each other as required by the inversion center located at the palladium atom, with the $\mathrm{Cl}$ $\mathrm{Pd}-\mathrm{N}(1)$ bond angle of $90.17(6)^{\circ}$. The $\mathrm{Pd}-\mathrm{Cl}$ and $\mathrm{Pd}-\mathrm{N}(1)$ bond lengths are 2.2921(9) and 2.008(2) ̊ respectively and are similar to those observed in the closely related $\left[\mathrm{PdCl}_{2}\left(\mathrm{~L}_{2}\right)\right],(\mathrm{Pd}-\mathrm{Cl}=2.274(2) \AA$ and $\mathrm{Pd}-\mathrm{N}=1.991(4) \AA$ ), where $\mathrm{L}=5$-phenoxy-1-phenyltetrazol ${ }^{16,17}$. The phenyl and tetrazole rings are essentially coplanar with the dihedral angle between their least-squares planes being $8.4(1)^{\circ}$. One intramolecular hydrogen bond was observed: $\mathrm{C}(7)-$ $\mathrm{H}(7) \ldots \mathrm{N}(4)$, with $\mathrm{C}(7) \ldots . \mathrm{N}(4)=2.827(3) \AA$ and $\mathrm{H}(7) \ldots \mathrm{N}(4)=$ $2.488 \AA$ A. No intermolecular H-bonds were found.

\section{Thermal properties and conclusions}

The phase transition and optical characteristics were investigated in the hope of detecting thermotropic mesomorphism for the ligands and complexes synthesized. Routine measurements of the melting points revealed very well defined melting points and no decomposition, however none of the ligands and complexes show thermotropic mesomorphism.

While in classic organic structures, the basic question is, frequently, to increase intermolecular contact to induce 


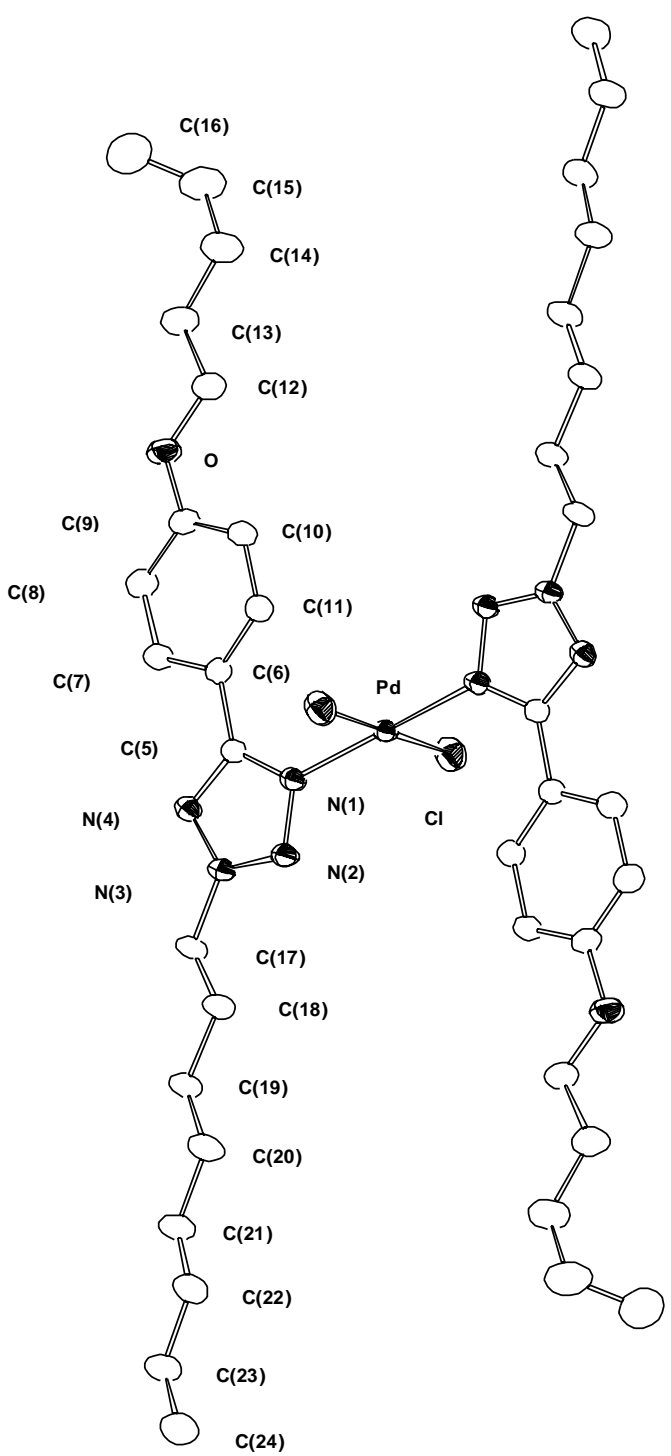

Figure 1. View of the structure of complex 3a trans- $\left[\mathrm{C}_{40} \mathrm{H}_{64} \mathrm{~N}_{8} \mathrm{O}_{2} \mathrm{PdCl}_{2}\right]$ showing the atom-labeling scheme. Displacement ellipsoids are shown at the $30 \%$ probability level. The $\mathrm{H}$ atoms were omitted for clarity.

mesomorphism, in coordination compounds the problem is to avoid intermolecular contacts (whenever a coordination site is accessible), and strong dipolar interactions (associated with the high polarizability of the transition metals), when sufficienttly strong to cause three dimensional order and consequently the absence of a mesophase.

Based on these considerations, the absence of mesomorphic behavior in the free ligands can be interpreted as being due to the reduced anisometry of the ligands because of the deviation from linearity caused by the substitution in the tetrazole ring, which leads to a decrease in the intermolecular contact. On the other hand mono- and dinuclear complexes do not exhibit a suitable structure to origin mesomorphism, since the two chlorine ligands are not in the same molecular plane of the phenyltetrazole molecules.

\section{Acknowledgements}

This work was supported by grants from $\mathrm{CNPq}$ and PRONEX.

\section{Supporting Information}

Crystallographic data have been deposited at the CCDC, 12 Union Road, Cambridge CB2 1EZ, UK and copies can be obtained on request, free of charge, by quoting the publication citation and the deposition number, 136758.

\section{References}

1. Giround-Godquin, A. M.; Maitlis, P. M.Angew. Chem. Int. Ed. Engl. 1991, 30, 375.

2. Espinet, P.; Esteruelas, M.A.; Oro, L.A.; Serrano, J. L. Coord. Chem. Rev. 1992, 117, 215.

3. Hudson, S. A.; Maitlis, P. M. Chem. Rev. 1993, 93, 861.

4. Bruce, D. W.; O'Hare, D. Inorganic Materials. Chichester, JohnWiley \& Sons, Ed. by Bruce, D.W. and O'Hare, D. 1992, Ch 8. pp. 405.

5. (a) Levelut, A. M. Liq. Cryst. 1995, 19, 2, 241. (b) Ghedini, M. Mol. Cryst. Liq. Cryst. 1987, 151, 75.

(c) Ghedini, M.; Licoccia, S.; Armentano, S.; Bartolino, R. Mol. Cryst. Liq. Cryst. 1984, 108, 269. (d) Marcos, M.; Ros, M. B.; Serrano, J. L. Liq. Cryst. 1988, 3, 1129.

6. (a) Praefcke, K.; Singer, D.; Gündogan, B. Mol. Cryst. Liq. Cryst. 1987, 223, 181. (b) Praefcke, K.; Diele, S.; Pickardt, J.; Gündogan, B.; Nütz, U.; Singer, S. Liq. Cryst. 1995, 18, 6, 857. (c) Crispini, A.; Ghedini, M.; Morrone, S.; Pucci, D.; Francescangeli, O. Liq. Cryst. 1996, 20, 67.

7. Finnegan, W. G.; Henry, R. A.; Lofquist, R. J. Am. Chem. Soc. 1958, 80, 3908.

8. Meyer, E.; Zucco, C.; Gallardo, H. J. Mater. Chem. 1998, 8, 1351.

9. Butler, R. N.; Mcevoy, T. M.; Scott, F. C.; Tobin, J. C. Can. J. Chem. 1977, 55, 1564.

10. Butler, R. N.; Garvin, V. C. J. Chem. Soc., PerkinTrans. 1981, $1,390$.

11. (a) Gómez, M.; Granell. J.; Martinez, M. Organometallics, 1997, 16, 2539. (b) Vila, J. M.; Gayoso, M.; Pereira, M. T.; Rodriguez, M. C.; Ortiguera, J. M.; Thomton-Pett, M. J. Organomet. Chem. 1992, 426, 267. (c) Hatimi, A. E.; Gómez, M.; Jansat, S.; Muller, G.; Font-Bardía, M.; Solans, X. J. Chem. Soc. Dalton Trans. 1998, 24, 4229.

12. (a) Garnovskii, A. D.; Sadimenko, A.P.; Sadimenko, M. I.; Garnovskii, D. A. Coord. Chem. Rev. 1998, 173, 
31. (b) John, E. O.;Willett, R. D.; Scott, B.; Kirchmeier, R. L.; Shreeve, J. M. Inorg. Chem. 1989, 28, 893. (c) Gaughan, A.P.; Bowman, K.S.; Dori, Z. Inorg. Chem. 1972, 11, 601. (d) Ziolo, R.F.; Thich, J.A.; Dori, Z. Inorg. Chem. 1972, 11, 626. (e) Trofimenko, S. Inorg. Chem. 1973, 12, 1215.

13. (a) Minghetti, G.; Stoccoro, S.; Cinellu, M. A.; Zucca, A.; Manassero, M.; Saansoni, M. J. Chem. Soc. Dalton Trans. 1998, 24, 4119. (b) Butler, I.S., Harrod, J. F. Inorganic Chemistry Principles and Aplications The Benjamin/Cumming Publishing Company, Inc. 1989, p 180.
14. (a) Newkome, G. N.; Puckett, W. E.; Gupta; V. K.; Kiefer, G. E. Chem. Rev. 1986, 86, 451. (b) Ryabov, A. D. Chem. Rev. 1990, 90, 403.

15. Zsolnai, L.; ZORTEP, An Interactive ORTEP Program. University of Heidelberg, Heidelberg, 1996.

16. Chadwick D. J.; Johnstone, R. A. W.; Price, P. J.; Harding, M. M. Acta Cryst. 1988, C44, 367.

17. (a) Minghetti, G.; Cinellu, M. A.; Bandini, A. L.; Banditelli, G.; Dermartin, F.; Manassero, M. J. Organomet. Chem. 1986, 315, 387. (b) Oshio, H.; Ohto, A.; Ito, T. Chem. Commun. 1996, 1541.

Received: November 17, 1999 